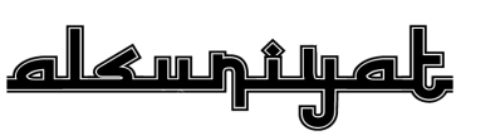

JURNAL PENELITIAN BAHASA, SASTRA, DAN

BUDAYA ARAB

P-ISSN: 2615-7241 | E-ISSN: 2721-480X // Vol. 4 No. 1 | 15-28

(1) https://ejournal.upi.edu/index.php/alsuniyat/index

\title{
How to Create Effective and Efficient Nahwu Media with Short Videos Based on the Camtasia Application?
}

\author{
Eka Utari Handayani, Rika Luthfiana Utami, Irvan Maulana Tamsil \\ Universitas Islam Negeri Sunan Kalijaga Yogyakarta, Indonesia \\ E-mail: alexautary@gmail.com
}

\begin{abstract}
:
Language learning is a complex process and requires extra effort. The limited allocation of learning duration is the root of the problem; At the beginner level, the nahwu rules are considered very difficult, especially for students from public schools and have never studied Arabic previously. Making videos based on the Camtasia Studio 8 application is one of the ways to encourage students to comprehend, leading to mastery of the nahwu rules. This study used the waterfall method, which consisted of requirements and analysis, design, implementation and unit testing, system testing, operation, and maintenance. This research aims to create learning media that is relevant to the era, effective, and efficient. The result indicates that video media is quite efficient and effective in supporting students' understanding of $n a h w u$ rules. This three-minute video can contain materials and examples within a short duration. Hence, the students do not get bored quickly and can focus on listening to it.

Keywords:

Camtasia Studio 8; Learning Media; Naḥwu Rules
\end{abstract}

\section{INTRODUCTION}

In teaching and learning the Arabic process, there are always many problems. It is caused by factors that might come from the teachers, students, classroom, school infrastructure, milieu, and family. Teaching is not an easy job, teaching is not only telling stories, and teaching is not only transferring knowledge or teach knowledge to students. Likewise, with learning, not all things taught in class are automatically reflected in students' minds. Learning requires mental involvement, feelings, and hard work from the students themselves (Machmudah \& Rosyidi, 2008).

Learning languages cannot be equated with learning other sciences. Learning a language requires a substantial effort; it is not surprising that sometimes learning a language feels dull and even frustrates someone (Machmudah \& Rosyidi, 2008). Students tend to think Arabic subjects are dull and unattractive due to their lack of creativity in creating a conducive learning atmosphere. It is not uncommon for students to think of Arabic as a complicated subject.

Language learning is not sufficient if it is only based on the allocation of learning time in class; this is because in learning Arabic itself, several aspects must be possessed by students, including aspects of linguistic elements (naḥwu, șaraf, and balāgah) and aspects of language 
ALSUNIYAT: Jurnal Penelitian Bahasa, Sastra, dan Budaya Arab

skills (istimā', kalām, qirā'ah, and kitābah) (Muhajir, 2017: 5). The very closely related aspects of linguistic elements are nahwu and nerves, both of which cannot be separated and are two things that must be mastered and learned by language learners. Naḥwu is a rule in the Arabic language that discusses changing the end of sentences and sentence positions. Nahwu is considered difficult for Arabic learners, especially for beginners who are learning Arabic for the first time; learning nahwu is very difficult to learn, moreover for the students who come from public schools and have never learned Arabic at all.

The difficulty of learning nahwu is due to a lack of motivation and support from various sides; the methods taught in naḥwu learning are less varied, making Arabic learners less interested in participating in nahwu learning (Nurtresnaningsih, 2018). If reviewed, the time for Arabic lessons at school is not as much as other lessons; this can also lead to students' lack of understanding and mastery of the material (Wahdah, 2018). Besides, the competence of Arabic teachers still lacks, especially in the subject of nahwu rules. Along with the emergence of the Covid-19 outbreak, the impact affects learning, where schools require online learning (Umamah \& Muassomah, 2020). Thus teachers are required to be creative and innovative in making learning media (Andriani, 2018).

With the many problems above, a media that can help and make it easier for students to learn is needed. In this case, students need media that can teach as teachers transfer their knowledge in the classroom. Students also need learning media that is according to their times, modern, economical, and flexible. It seems that audio-visual (video) learning media can be used as an alternative answer to these worries and problems. So it is not an exaggeration to assume that video media can contribute to answering all these problems.

Learning with videos can provide information in different ways to a student is so that students do not find it difficult to absorb the information; even learning can be fun. Learning videos in the form of video tutorials will provide general information and practice students' thinking skills. Supported by Mestre's statement in Clossen that "videos present information in a decidedly different way than more static combinations of screenshots and text, thus making them great tools for communicating, especially with textual, visual learners"; this means that videos present information differently, which makes videos an excellent medium for sharing information (Septianty et al., 2018).

Learning by using media can help students build the same perception of learning so that there are no misunderstandings in understanding the subject matter. The development of 
ALSUNIYAT: Jurnal Penelitian Bahasa, Sastra, dan Budaya Arab

science and technology has had an impact on various fields of education. This development has provided renewal efforts in using technology results in the form of a learning medium. The use of media in learning can increase learning motivation, stimulate learning activities, and affect students' psychological effects (Erniasih et al., 2018).

Several studies mention the same thing in line with several factors, including Moh's scientific work. Putra et al. with the title "Development of Learning Media Based on Camtasia Multimedia Interactive CD Video Studio for Web Programming Subjects in the Multimedia Department of SMK Negeri 3 Singaraja". The results showed that the learning media developed with Camtasia Interactive Video Studio could be an appropriate and feasible learning medium. Interactive multimedia video CD media follow the syllabus indicators (Putra et al., 2017).

The second study is a scientific paper written by Hakim et al. with an article entitled "The Use of Video Turorial with Camtasia to Improve and Student Learning Outcomes of Drawing with Software in Class X TGB B Students of SMK Negeri 4 Sukoharjo in the 2016/2017 Academic Year". This study shows that video tutorial media using Camtasia can increase student demand in cycle one by $72.14 \%$ with a percentage of $75 \%$ completeness to $78.81 \%$ in cycle 2 . The increase in learning outcomes from pre-cycle is $45.71 \%$ to $71,43 \%$ in cycle 1 and $80.00 \%$ in cycle 2. Thus; it can be concluded that the application of video tutorial media with Camtasia can increase student learning demands and outcomes (Hakim et al., 2017).

The researchers' video media's similarity with the two previous studies is that they both use the Camtasia application. The difference is that in this study, the researcher only measures the effectiveness and efficiency of time and the feasibility of this video media to be used as an example of Arabic learning media.

Video is a medium for delivering messages, including audio-visual media or viewinglistening media. Audio-visual media can be divided into two types: first, equipped with sound and image equipment functions in one unit, called pure audio-visual media, and second, impure audio-visual media. Moving films, such as television, and video, are of the first type, while slides, opaque, OHP, and other visual equipment are given sound is of the second type. One of the learning media in the form of videos that can be used as a subject to facilitate the learning process and make it easier for teachers to deliver subject to students is Camtasia Studio 8. Camtasia Studio 8 is a software used to make videos that are displayed directly from a computer screen. Camtasia Studio 8, and providing convenience to teachers in transfer knowledge, can make it easier for students to receive lessons quickly and interestingly. Camtasia Studio 8 can 
ALSUNIYAT: Jurnal Penelitian Bahasa, Sastra, dan Budaya Arab

also be an alternative to updating methods and learning strategies, especially learn Arabic naḥwu rules, to be more interested in taking Arabic lessons.

Responding to some of the problems found in learning Arabic above and after examining the making of videos using the Camtasia studio application, it seems that research is needed regarding Arabic learning media with the Camtasia application's help; this is because of the ease of making videos using Camtasia which is an easy way to download an application. The tutorial for using it is also comprehensive and even more complete than other applications. In this study, the researchers made the video as short as possible and easy to understand. As we know that students get bored quickly if they see a tutorial video that is too long; in this video, the researcher presents it in a short duration but includes explanations and examples that are easy to understand. Learning media using this video is expected to bind, attract attention, make it easier to understand lessons and motivate students to be more creative (Dariyadi, 2016).

\section{METHOD}

The methodology is the main thing in designing and implementing a study to produce an information system that suits your needs. Developing a product depends on managing the software project (Budi et al., 2017). This research is based on the field's learning Arabic, especially the nahwu rules, combined with the Camtasia Studio 8 application. The data collection techniques used by researchers are interviews and documentation. This media was made based on several Arabic learning problems, especially the nahwu rules of students class VII MTS. The research method chosen by the researcher is the linear sequential model or waterfall.

The waterfall method is a systematic and sequential information system development model (Sasmito, 2017). In this research method, there are several scopes of activity that must be passed by researchers; in the first step are requirements analysis and definition (Budi et al., 2017). At this step, the researcher observed the problems related to the nahwu rule and an analysis of students' needs, class VII MTS, and teachers. Second, are the system and software design; this step is a plan design following the field's needs. Then the researchers provided a solution in the form of the Camtasia Studio 8 application, which can be displayed in video form. Third, implementation and unit testing. At this step, the researcher shows the application design in the form of a video. In the video, few nahwu rules are presented, along with examples in line with the seventh-grade learning subject. Fourth, integration and system testing. At this step, the researcher conducted a feasibility trial where the researcher asked the UIN Sunan 
ALSUNIYAT: Jurnal Penelitian Bahasa, Sastra, dan Budaya Arab

Kalijaga, postgraduate students of study Arabic Language Education, as the test object. Fifth, operation and maintenance. At this step, the researchers conducted expert validation. The media experts who validated this video are professors in the Arabic Language Education study program's learning media course (Yusuf \& Rahmawati, 2020).

\section{RESULTS AND DISCUSSION}

\section{Video Learning Media}

According to Gagne and Brings (at Arsyad, 2011), learning media includes tools that can convey teaching subjects such as books, videos, tapes, films, etc. According to Al Fauzan (at Hamid et al., 2008), in general, language teaching media are grouped into three groups there are media devices, learning subject media, and learning support activities. There are hearing and sight devices in the device media in TV, video, LCD, and electronic devices such as computers.

Video learning media is critical and needs to be developed because learning media can simultaneously present audio and visual elements of motion. Video as an audio-visual motion learning subject will attract elementary school students' attention and motivation in carrying out learning activities. This video learning material will be more attractive to students because it can present real objects that are far away, dangerous, and maybe they have never seen it (Muga, 2016).

Produce a learning video that can increase motivation and effectiveness for its users; learning videos must pay attention to the characteristics and criteria. The characteristics of the learning videos are: First: Clarity of Massage (textuality of the message) With video media, students can understand learning messages more meaningfully, and information can be received entirely so that the information will automatically be stored in long-term memory and are retention in nature; second: Stand Alone (stand-alone). The video developed does not depend on other teaching materials or does not have to be used together with other teaching materials; third: User Friendly (familiar with the user). Video media uses simple language, easy to understand, and uses familiar language. Information exposure that appears is helpful and friendly to the user, including the ease with which the user responds and accesses as desired; fourth: Representation of the Content The subject must be genuinely representative such as material for simulation or demonstration. Both social and science subject matter can be made into video media; fifth: Visualization with media. According to the subject's demands, the subject is packaged in multimedia, including text, animation, sound, and video. The subjects 
ALSUNIYAT: Jurnal Penelitian Bahasa, Sastra, dan Budaya Arab

used are applicative, processed, difficult to reach, dangerous if practiced directly, have a high degree of accuracy; sixth: Using high-resolution quality. Display in the form of video media graphics made with digital engineering technology with high resolution but support for every computer system speech; seventh: Can be used classically or individually. Instructional videos can be used by students individually, not only in school settings but also at home. It can also be used classically with a maximum amount of students. It can be guided by the teacher or listen to the narrator's narrative description already available in the program.

While the characteristics of instructional video media according to Arsyad (2004) are as follows: 1) Can be stored and used repeatedly; 2) Must have a particular technique for arranging the order both in terms of serving and storage; 3) Operation is relatively easy; 4) Can present past events or events in other places.

\section{Camtasia Studio 8}

Camtasia Studio is a software that can record everything that is happening on the monitor screen. Therefore, this software is usually used to make video tutorials or video presentations. This software is straightforward to use, and the results are quite satisfying. The video tutorials' material can easily reach or be captured by most people (Enterprise, 2015). Camtasia Studio a software developed by TechSmith Corporation, specializing in multimedia. Camtasia Studio is an application program packaged for recording, editing, and publicity in making video presentations on a computer screen.

Camtasia Studio is a software that captures the monitor screen, with added audio or video; we can also use it to record the results of PowerPoint presentations into video format. Camtasia Studio can help and train us in conveying and interacting with the audience. Camtasia Studio can record on-screen sound, including desktop activities, PowerPoint presentations, voice narrations, and video webcams. Camtasia Studio is one of the complete solutions for creating professional videos and PC desktop activities quickly. Anyone can record and create a motion lesson or presentation (Putra et al., 2017). Camtasia Studio is a software designed to produce video directly from a computer screen and edit video (screen recording \& video editing software). In general, there are three features offered at Camtasia Studio; there are: record the screen, record voice narration, and record power points (all three will appear on the initial screen). Apart from these three things, there is also a webcam record (Tim Dosen Pendidikan Kimia UII, 2017). 
ALSUNIYAT: Jurnal Penelitian Bahasa, Sastra, dan Budaya Arab

According to Oktaviani, Camtasia Studio is a software/multimedia device that functions to record activities on a computer. With this software/device, anyone who uses it can record all of their computer activities in high quality and super good High Definition (HD) and can also edit video and audio files. The program in Camtasia Studio allows files to be saved in their format and not combined with other formats, where the format can only be read by Camtasia Studio itself; this format allows for a file size that is small enough so that it can be saved with small file size, even used for more. Lots of presentations. Camtasia Studio can also allow the resulting video stream to be exported to a standard video format readable by most computers. In contrast, Camtasia Studio can produce videos that other computers can also access, even if Camtasia software is not installed, such as MPEG-2 or MPEG-4 (Awaludin et al., 2019).

There are six main sections in Camtasia Studio that you should know (Enterprise, 2015):

1. Main Toolbar, which contains buttons associated with general options regarding the document/project.

2. Task List gives access to options for recording, editing the timeline, and options for producing videos.

3. Clip Bin is a place to store all the files included in a project.

4. Preview Window is a window that will play clips from the clip bin or from the timeline. As well as displaying what the video being worked on will look like.

5. Timeline Toolbar provides basic editing options like split video, trim, add audio track, and volume adjustment.

6. A timeline is a place to do the editing and stitching of the entire video. In this timeline, a sequence of all existing clips will be displayed along with effects and elements from other videos.

\section{Learning Nahwu for Class VII MTS}

Learning is a process in which there are teaching and learning activities and various things that enhance the process, such as teachers, students, subjects, media, methods, infrastructure, and other situations. Learning can also be interpreted as an active process of learners who develop their potential. According to Sa'adah (2019) students are involved thoughtfully and emotionally in a learning activity that is fun, challenging, and encourages student initiative; this is one way for students to enjoy learning. 
ALSUNIYAT: Jurnal Penelitian Bahasa, Sastra, dan Budaya Arab

Learning Arabic has several objectives, including understanding in terms of form, meaning, and function. It can use it appropriately and creatively; learners can use Arabic to improve intellectual, emotional, and social maturity; learners have discipline in thinking and language (speaking and writing). The scope of Arabic learning includes language, language skills, and cultural and written aspects in oral and written texts. The language element itself consists of three elements, namely, grammar (qawāidu al-lugah), vocabulary (mufradāt), and pronunciation or spelling (așwāt 'arabiyyah) (Hamid et al., 2008).

In terminology, the meaning of nahwu is a collection of several rules or formulas used to find out of Arabic or the form of Arabic patterns either independently or structurally with other words. Nahwwu and șaraf's knowledge is needed in learning Arabic because a word can change its meaning and meaning due to changes in i'rāb and changes in its origin. (Sari, 2017). The purpose of learning nahwu rules is to make it easier for Arabic learners to master the language elements, master every language skill, form sentences both spoken and written, and avoid language errors. Writing or scientific work that uses nahwu rules appropriately will make it easier for readers to understand the writing while speaking in a speech that uses correct nahwu will make it easier for listeners to understand the speech's contents. That is the significance of understanding and practice of nahwu science.

For basic level Arabic learners, the provision of nahwu science material has not been overemphasized. However, at the intermediate level, students are given basic nahwu knowledge and are trained to practice it in a sentence in written or spoken form. Then at the advanced stage, students are more emphasized on understanding, practice, and deepening the science of $n a h w u$.

In the Arabic book published by the Ministry of Religion in 2014, nahwu learning is included in mufradāt and tarākib (Albantani et al., 2020). The following are some of the nahwu rules subject found in books published by the Ministry of Religion, especially class VII. In the third chapter, there are adverbs of place and examples and adjectives, along with examples.

\section{Design}

The design process is a step in converting requirements into software-like characteristics before starting program writing. The making of video learning media using the Camtasia Studio 8 application has several designs and display sequences displayed in the approximately 4-minute video. The purpose of designing and planning a video is to make the 
ALSUNIYAT: Jurnal Penelitian Bahasa, Sastra, dan Budaya Arab

video impressive, and the material contained is easy for students to understand. The following is the learning video design. There are many other harf jar, but in this study, the researchers only chose three harfjar that are most often used in everyday life.

\section{Figure 1. Design of a Learning Video}

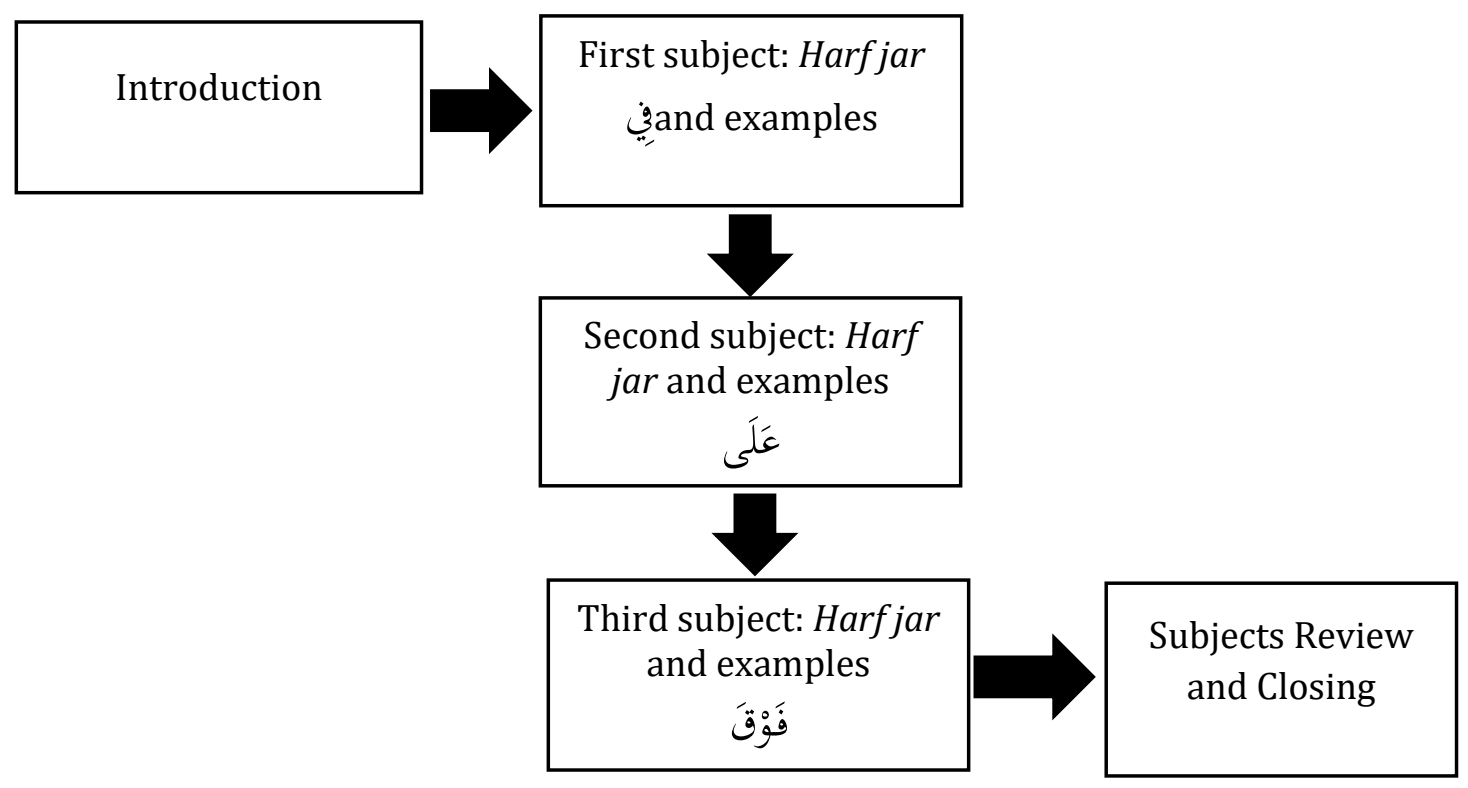

After completing the video design, the researchers began to apply the idea in Camtasia Studio 8.

\section{Opening}

Figure 2. Opening View
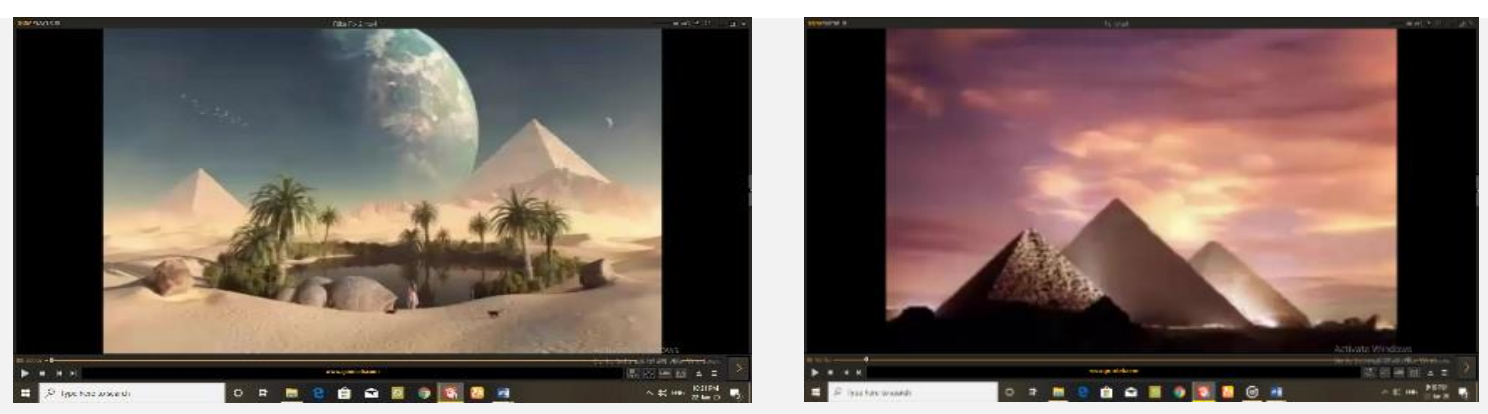

The researcher presented the Arabian landscape atmosphere; this is done to make students feel more deeply absorbed and imagine the Arabian country's beautiful scenery. Besides that, the initial appearance with one of the destinations in the desert also aims that 
ALSUNIYAT: Jurnal Penelitian Bahasa, Sastra, dan Budaya Arab

learning Arabic is related to religion, but Arabic is a language that can be learned with the aim of mastering foreign languages and increase knowledge of a country's culture; this is the same as other languages such as English, Spanish, Korean and so on.

\section{Subjects}

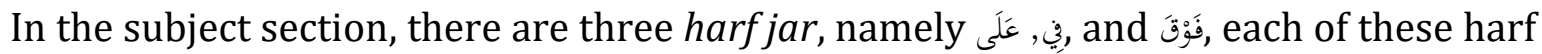
is given an explanation and examples in the form of a sentence. In the first material, namely, students are given examples that are easy to understand and examples of the application of the word in different meanings.

Figure 3. Harf Jar Subject
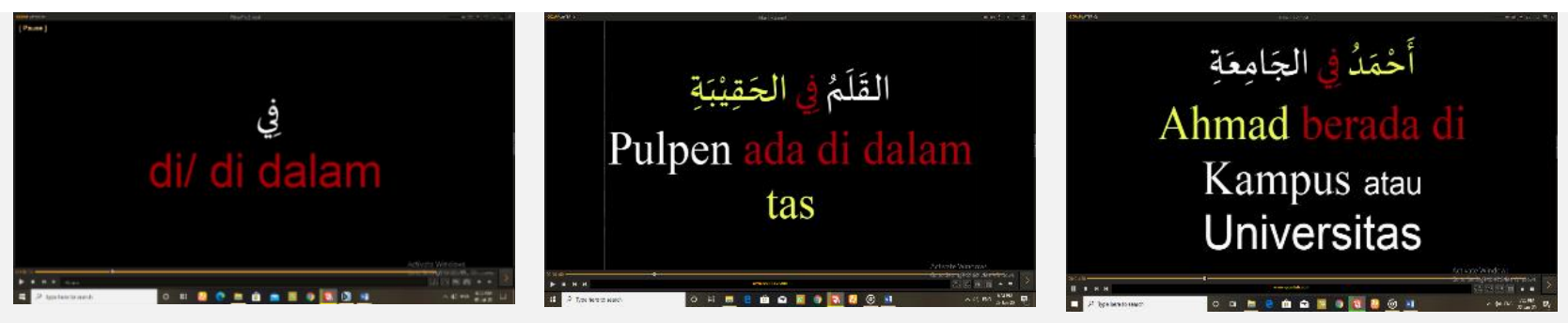

Fَلَى Figure 4. Harf Jar Subject
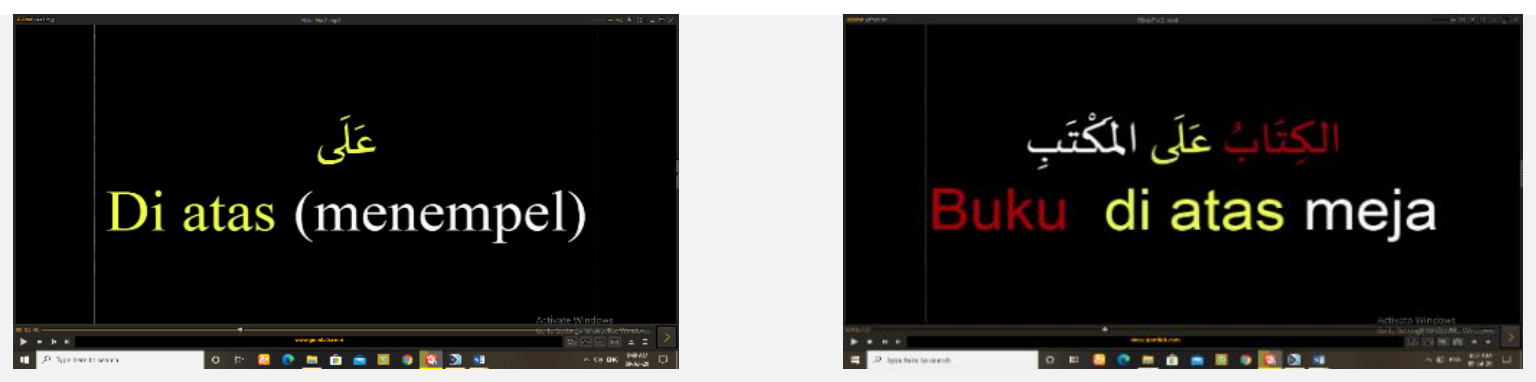

فَوْقَ Figure 5. Harf Jar Subject
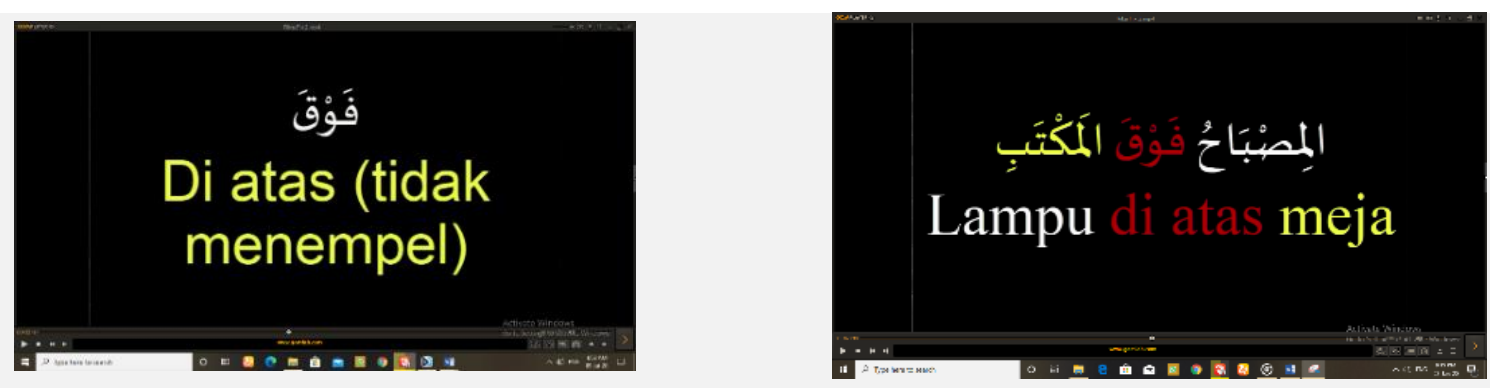

Vol. 4 No. 1 | 15-28

AISUNIYAT, p-ISSN: 2615-7241, e-ISSN: 2721-480X 
ALSUNIYAT: Jurnal Penelitian Bahasa, Sastra, dan Budaya Arab

In the subject section, فَوَق a عَكَ students are explained the difference in the meaning and use of the two words correctly and correctly, and students are given examples of each word in the form of a sentence. The purpose of the slides is to avoid mistakes in using the word both orally and in writing.

Figure 6. Subjects Review and Closing
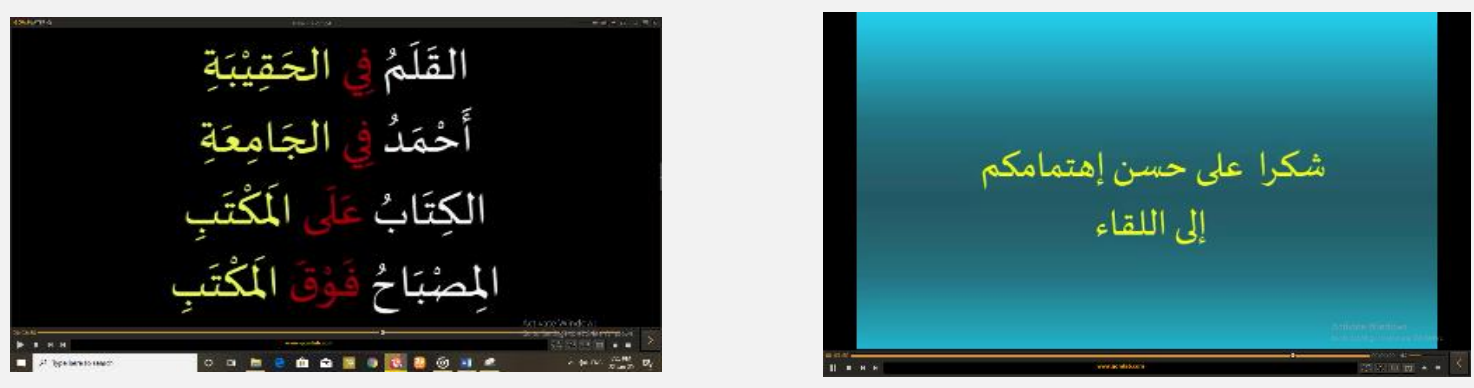

\section{Closing}

The closing section consists of several parts, including a:

1. Review the subject; In this section, students are invited to review previously given subjects and pronunciation exercises in the form of one short sentence.

2. In this section, the tutor urges and invites students not to feel ashamed of practicing speaking Arabic. Students also do not need to pay attention to nahwu rules in practicing speaking Arabic.

3. Arabic song; this song aims to attract students' interest in listening to Arabic songs. Arabic songs can also train students in listening to Arabic speech that is following the native speaking way. With music, students will not feel bored in learning, so that students can enjoy learning in a relaxed and comfortable manner. Besides that, the video duration is relatively short and will not make students feel overwhelmed. In other words, learning will be more flexible and time-efficient.

The full version of the learning video can be accessed via this link http://gg.gg/VideoKata-Keterangan-Tempat-Camtasia.

\section{CONCLUSION}

One of the steps teachers must take in increasing student interest in learning is increasing student enthusiasm for learning, creating modern, and keeping up with the times using video learning media. Learning with video media is also not limited by time, efficient, and more economical. Besides that, with a reasonably short video duration, students are not easily 
ALSUNIYAT: Jurnal Penelitian Bahasa, Sastra, dan Budaya Arab

bored and are more effective in absorbing knowledge because the video already contains explanations and examples that are easy for students to understand. Also, students can access learning wherever and whenever they want. Especially during this pandemic, many students needed video tutorials to understand learning, and finally, this short video can also be uploaded on the YouTube channel.

Requirements analysis, design, and planning, and validation tests are indispensable in making appropriate media. Making videos using the Camtasia Studio 8 application can be an alternative media used by teachers in learning both on naḥwu material and in Arabic language proficiency training. It is hoped that this article can be useful for foreign language education students, especially Arabic, and can be an inspiration for Arabic teachers to make learning media. The advantages of making videos using the Camtasia application are; It is easy to download the Camtasia application, there are many video tutorials and easy to find, making videos is more comfortable than other applications. By using this application, the video maker is more efficient in the use of time.

\section{REFERENCES}

Albantani, A. M., Fauziah, A. U., \& Sumiantia, I. (2020). Perkembangan kosakata bahasa Arab melalui isytiqāq. Alsuniyat: Jurnal Penelitian Bahasa, Sastra, dan Budaya Arab, 3(2), 125138. https://doi.org/10.17509/alsuniyat.v3i2.26243

Andriani, N. (2018). Problematika siswa pada qirā'ah jahriyyah teks bahasa Arab serta upaya perbaikannya di SMK Yapari Aktripa Bandung. Alsuniyat: Jurnal Penelitian Bahasa, Sastra, dan Budaya Arab, 1(2), 146-159. https://doi.org/10.17509/alsuniyat.v1i2.23831

Arsyad, A. (2011). Media pembelajaran. Jakarta: Rajawali Press.

Awaludin A. A. R., Hartuti P. M., \& Rahadyan, A. (2019). Aplikasi Cabri 3D berbantu Camtasia Studio untuk pembelajaran matematika di SMP. E-DIMAS: Jurnal Pengabdian Kepada Masyarakat, 10(1). https://doi.org/10.26877/e-dimas.v10i1.2872

Budi, D. S., Siswa, T. A. Y., \& Abijono, H. (2017). Analisis pemilihan penerapan proyek metodologi pengembangan rekayasa perangkat lunak. Teknika, 5(1), 24-31. https://doi.org/10.34148/teknika.v5i1.48

Dariyadi, M. W. (2016). Penggunaan software Camtasia Studio sebagai media pembelajaran bahasa Arab berbasis ICT. Prosiding Konferensi Nasional Bahasa Arab (KONASBARA) II. Malang: 15 Oktober 2016, 207-219. 
ALSUNIYAT: Jurnal Penelitian Bahasa, Sastra, dan Budaya Arab

Enterprise, J. (2015). Membuat video tutorial menggunakan Camtasia. Jakarta: PT Elex Media Komputindo.

Erniasih, U., Pramono, S. E., \& Atno. (2018). Perbedaan hasil belajar dengan menggunakan media video edukasi dan media video dokumenter pada pembelajaran sejarah di SMAN 12 Semarang tahun ajaran 2017/2018. Indonesian Journal of History Education, 6(2), 162171.

Hakim I. C., Sukatiman, \& Siswanto, B. (2017). Pemanfaatan video tutorial dengan Camtasia untuk meningkatkan minat dan hasil belajar siswa dalam pembelajaran menggambar dengan perangkat lunak pada siswa kelas X TGB B di SMK Negeri 4 Sukoharjo tahun ajaran 2016/2017. Indonesian Journal of Civil Engineering Education, 3(2), 1-16. https://doi.org/10.20961/ijcee.v1i2.18242

Hamid, M. A., Baharuddin, U., \& Mustafa, B. (2008). Pembelajaran bahasa Arab: Pendekatan, metode, strategi, materi dan media. Malang: UIN Malang Press.

Machmudah, U., \& Rosyidi, A. W. (2008). Active learning dalam pembelajaran bahasa Arab. Malang: UIN Malang Press.

Muga, W. (2016). Desain pembelajaran quantum berbantuan video untuk meningkatkan hasil belajar psikomotorik. 1st Annual Proceeding. Nusa Tenggara Timur: Juni 2018, 130-147.

Muhajir. (2017). Arah baru pengajaran bahasa Arab filsafat bahasa, metode dan pengembangan kurikulum (1st ed.). Yogyakarta: Fakultas Tarbiyah dan Ilmu Keguruan UIN Sunan Kalijaga.

Nurtresnaningsih, I. (2018). Problematika siswa dalam pembelajaran bahasa Arab serta upaya dalam menanggulanginya. Alsuniyat: Jurnal Penelitian Bahasa, Sastra, dan Budaya Arab, 1(1), 17-29. https://doi.org/10.17509/alsuniyat.v1il.24196

Putra, I., Ariawan K. U., \& Sutaya, W. (2017). Pengembangan media pembelajaran berbasis Camtasia Studio video CD interaktif multimedia untuk mata pelajaran pemrograman web di jurusan multimedia SMK Negeri 3 Singaraja. Jurnal Pendidikan Teknik Elektro Undiksha, 6(1), 4. https://doi.org/10.23887/jjpte.v6i1.20225

Sa'adah, N. (2019). Problematika pembelajaran nahwu bagi tingkat pemula menggunakan Arab pegon. Lisanan Arabiya: Jurnal Pendidikan Bahasa Arab, 3(01), 15-32. https://doi.org/10.32699/liar.v3i01.995

Sari, A. W. (2017). Analisis kesulitan pembelajaran nahwu pada siswa kelas VIII Mts Al Irsyad Gajah Demak tahun ajaran 2015/2016. Journal of Arabic Learning and Teaching Lisanul Arab, 6(1), 16-20. https://doi.org/10.15294/la.v6i1.14388 
ALSUNIYAT: Jurnal Penelitian Bahasa, Sastra, dan Budaya Arab

Sasmito, G. W. (2017). Penerapan metode waterfall pada desain sistem informasi geografis industri Kabupaten Tegal. Jurnal Informatika: Jurnal Pengembangan IT (JPIT), 2(1), 6-12. http://dx.doi.org/10.30591/jpit.v2i1.435

Septianty, R. D. P., Maharta, N., Suana, W., Lampung, U., Soemantri Brojonegoro No, J., \& Lampung, B. (2018). Pengembangan video tutorial latihan berpikir kritis pada materi kelistrikan. Journal of Physics and Science Learning, 02(1), 59-68.

Tim Dosen Pendidikan Kimia UII. (2017). Modul pelatihan media pembelajaran (pembuatan video tutorial dengan Camtasia 7/8.4). Musyawarah Guru Mata Pelajaran (MGMP) Kimia.

Umamah, M., \& Muassomah, M. (2020). Pembelajaran daring melalui teknik kolaboratif pada keterampilan menulis peserta didik di SMA Darul Qur'an Kota Mojokerto. Alsuniyat: Jurnal Penelitian Bahasa, Sastra, dan Budaya Arab, 3(2), 88-100. https://doi.org/10.17509/alsuniyat.v3i2.24362

Wahdah, Y. A. (2018). Faktor-faktor kesulitan siswa dalam membaca teks bahasa Arab. Alsuniyat: Jurnal Penelitian Bahasa, Sastra, dan Budaya Arab, 1(1), 30-46. https://doi.org/10.17509/alsuniyat.v1i1.24197

Yusuf, M., \& Rahmawati, E. D. (2020). Optimalisasi aplikasi Macromedia Flash 8 dalam pembelajaran kosakata bahasa Arab. Al-Lisan, 6(1), 17-33. https://doi.org/10.30603/al.v6i1.1102 